\title{
Relational Goods and Their Subjects: The Ferment of a New Civil Society and Civil Democracy
}

\author{
Los bienes relacionales y sus sujetos: el germen de una \\ nueva sociedad civil y democracia civil
}

PIERPAOLO DONATI

UNIVERSITÀ DI BOLOGNA

Received: 04 July 2013

Accepted: 07 October 2013

\begin{abstract}
From some years now, the social sciences have been highlighting the existence of a type of goods that are neither material things, nor ideas, nor functional performances but consist, instead, of social relations and, for this reason, are called relational goods. This contribution proposes to clarify this concept from the viewpoint of relational sociology, which avoids both methodological individualism and holism. Subsequently, it argues that such goods can be produced only by specific social subjects, which the author calls «relational subjects». Relying upon many theoretical and empirical researches, the paper explains in which sense and in which way relational subjects, and the goods they generate, can contribute to making civil society more robust: that is, no longer the typically capitalist society of the market, but an «associational» society able to sustain a mature democracy.
\end{abstract}

Keywords: relational goods, relational sociology, relational subjects, civil society, civil democracy.

Resumen

Desde hace algunos años, las ciencias sociales han resaltado la existencia de un tipo de bienes que no son ni cosas materiales, ni ideas, ni prestaciones funcionales pero que consisten, en cambio, en relaciones sociales. Por esta razón se les llama bienes relacionales. Este texto propone aclarar este concepto desde el punto de vista de la sociología relacional, evitando tanto el individualismo como el holismo metodológico. Posteriormente, se argumenta que tales bienes pueden ser producidos únicamente por sujetos sociales específicos, que el autor denomina como «sujetos relacionales». Apoyándose en numerosas investigaciones teóricas y empíricas, el texto explica en qué sentido y de qué manera los sujetos relacionales, y los bienes que generan, pueden contribuir a que la sociedad civil sea más robusta. Entendiéndola no como la sociedad típicamente capitalista de mercado, sino como una sociedad «asociativa» capaz de sostener una democracia madura. 
Palabras clave: bienes relacionales, sociología relacional, sujetos relacionales, sociedad civil, democracia civil

\section{IN SEARCH OF 'OTHER GOODS' THAT CONFER SOLIDITY ON A ROBUST DEMOCRATIC CIVIL SOCIETY}

For some years now the social sciences have been highlighting the existence of a type of goods that are neither material things, nor ideas, nor functional performances but consist, instead, of social relations and, for this reason, are called relational goods.

This contribution proposes, first of all, to clarify this concept and, subsequently, to show that such goods can be produced only by specific social subjects, which I call «relational subjects». We shall then see in which sense and in which way relational subjects, and the goods they generate, can contribute to making civil society more robust: that is, no longer the typically modern civil society - the bourgeois society of the market- but an «associational» society able to sustain a mature democracy as a welfare society's form of governance.

It is important to emphasize from the beginning that the type of goods that I call relational cannot be traced back to traditional or premodern forms of social organization because they require conditions that only modernity has created by making individuals more free and guaranteeing the maximum amount of social mobility. For a long time these goods have been dismissed or even repressed by capitalistic society as well as by societies dominated by dictatorships. Today they are emerging as the yeast of an advanced democracy.They are created precisely where relations between consociates are tendentially symmetrical (not hierarchical), free, and responsible (not constrained by authoritative norms or powers), not mercantile or, in any case, not dictated by the pursuit of individual profit.

Empirical studies show how widespread they really are. These are goods that are invisible to the naked eye (they are intangible goods) and are continually sought out by people, but they come into existence only under particular conditions. As examples we could think of goods such as the following: trust between people or families in difficulty who are willing to help one another; a collaborative and serene climate in a company; the feeling of safety among the residents of a neighborhood; a social or health service able to improve the quality of relations between parents and offspring; the spirit of collaboration in a sports team; cooperation among members of an orchestra; an internet site that receives and gives useful information to a group of people interested in that service; and so on. Our life is a continual search for 
relational goods, but we have a very limited awareness of what they are and how they can be generated and regenerated.

We are seeing a relational good when the participating individuals themselves produce and enjoy it together. An example is the collaboration in a scientific research team. The participants can be not only individuals, but groups or social networks too. In the latter case, the relational goods take on a more complex organizational character. For instance, we could think of small associations of families constituting a second level network or association with goals of reciprocal mutuality; another example is volunteerism among single local associations. Or we could think of a second level network among single social cooperatives that create a fabric of strong cohesion and social solidarity in a certain territory. The relational good, in other words, primarily concerns people and their relations (primary goods). But it can also be situated at a level of secondary relations among people who do not directly know one another, as a result of their sharing an associative affiliation (in these cases, relational goods are said to be secondary because they do not involve face-to-face relations). ${ }^{17}$

In essence, relational goods have the following properties: they are not «things» but consist of social relations that have a sui generis reality; they are produced and enjoyed together by those who participate in them; the good that they entail is an emergent effect which redounds to the benefit of participants as well as of those who share in its repercussions from the outside, without any single subject's having the ability to appropriate it for him/herself. Relational goods have an intrinsically democratic character in that they distinguish themselves from bureaucratic organizations (such as the public administration) that act on command and generate goods that redound to their surrounding community's benefit (whether territorial or not). They are not particularistic and closed goods, such as those sought by groups connected to lobbyists or the mafia. Perhaps the best way to understand them is to refer to Alexis de Tocqueville's key concept when he showed that the fundamental source of nourishment for a modern liberal-democratic society is «the art of associationism.» He gave an essentially civic version of this. For Tocqueville, in fact, democratic associations are those that gather together citizens in order to solve the problems of a political community (such as, for example, creating a public garden or placing a fountain in a square). Today we have at our disposal a more extensive and refined theory of those goods that pertain to the art of associating for civic and civil ends. ${ }^{2}$

1 For more details and empirical evidences see Donati and Solci (2011).

2 On the distinction between the terms "civil value and "civic value» see Cortina et al. (2008) and Pollini (2009: 19-80). 


\section{RELATIONAL GOODS ARE A REALITY THAT ESCAPES THE PUBLIC/PRIVATE DICHOTOMY}

The concept of relational good arises primarily from dissatisfaction with a dichotomy, introduced by modernity, between public and private, which separates and classifies every type of good into one or the other domain. That which is public is understood to be accessible to everyone and impersonal. That which is private is understood to be available only to autonomous subjects who are its owners. Consequently, society is distinguished into a public sphere, in which sociality is neutral and open, and a private sphere, in which sociality is particularistic and closed. It is obvious to ask: is there nothing in between? And in addition: if by chance there were something in between, would this possible «third» not be such as to redefine the two poles of public and private?

Once modernity obliges the social organization to divide social goods into public as opposed to private goods, it generates evident gaps and vacuums. Where can we then seek out those goods in which the sociability of human persons and their social networks is expressed without such forms' having necessarily to be ascribed to the public or private arena?

With the term "Sociability» (Simmel, 1981: 121-136) I am referring to social relationality, which can be interpersonal (face-to-face) but also more impersonal (as in organizations or social movements in which it becomes synonymous with a sense of belonging) on condition that the latter is active and consists of reciprocal actions (even if at a distance) that generate emergent effects of a prosocial nature. Just to give a few examples, we could think of friendship and neighborhood networks, self-help and mutual aid networks, and small groups that carry out many initiatives to help the weakest and least fortunate members of society; or, at another level, there are social movements (whether local, global, or glocal) that actively intervene in civic problems and peer-to-peer social networks that produce shared goods on the internet. In all of these cases, it would be difficult to ascribe the initiatives to the strictly private or public arena.There is an «intermediate» social space that remains little explored.

The concept of relational good fills in the gap between private and public goods. It points to a reality in which certain aspects of what is private are intertwined with some aspects of what is public, without being either one or the other. In any case, relational goods are essential in order to make society less impoverished, risky, insecure, mistrustful, and pathological in many of its aspects. It is important to emphasize that these realities could not exist before modernity transformed the intermediate social sphere between pub- 
lic and private into a desert. Those who think of relational goods as a revival of things from the past that were typical of premodern society (such as the confraternities or charitable organizations) would be committing a serious error of perspective.

To say this better: the typically modern polarization between the public sphere (identified in the state) and the private sphere (identified in the capitalistic market) entails the birth of social forms that have a sociability of which the quality is different from the forms present in traditional societies, such as the medieval religious confraternities, the monte di pietà, the charitable entities for the poor and sick, and other similar institutions. The reason for the difference lies in the processes of multiplication of the intersecting circles that produce a new individuality ${ }^{3}$ and, consequently, a different type of sociability. In premodern societies the forms of sociability that create relational goods are generally of an ascriptive and asymmetrical type as regards power relationships: the positions of those who participate are not egalitarian but reflect stratification by class. In modernized societies, instead, they are of an acquisitive and tendentially symmetrical type as regards the power relationships among participants in as much as the old social stratification diminishes and a principle of equality asserts itself.

The notion of the relational good emerges when one becomes aware of the existence of other goods that are neither available on the basis of the prerogative of private ownership nor accessible to everyone indiscriminately. They are goods that do not have an owner, nor are they of the generically understood collectivity. They are the goods of human sociability, goods that are crucial for the very existence of society, which could not survive without them. If these goods are ignored dismissed, or repressed, the entire social fabric is impoverished, mutilated, and deprived of life blood with serious harm caused to people and the overall social organization. Those who do not understand this point or seek to trace relational goods to either the public or private arena fail completely to understand relational goods' meaning, mode of being, functions, and social value. Let us consider a few examples of relational goods.

A group of parents decides to constitute an association for organizing educational services for their own children, which will also be available to other children in the community, and they obtain spaces and payment for utilities from the municipality while they themselves manage the actual service (for example, a nursery, pre-school, or primary school): is this initiative

3 We owe to Georg Simmel the idea that the individualization of people is increasingly enhanced the greater the number of «social circles» (associations, groups, communication and exchange networks) in which individuals participate: cf. Simmel (1972). 
public or private? To modern eyes it would be private because the parents manage it, but the agreement with the municipality complicates things since it takes place on public property, and, moreover, the agreement with the municipality stipulates accountability and inspections, or supervision, at the very least. Everyone sees that here the public/private categories do not grasp the initiative's more truly social nature.

A group of families that share a given problem (they have a disabled child, a non-autonomous elderly relative, an alcoholic or dependent family member, etc.) create an association to help one another in turn (mutual aid) and to take actions of advocacy (demanding rights), both for themselves as well as for the other families facing the same situation: is this association private or public? There is no doubt that it is private, but does it correspond to modernity's definition of the private (according to which the private is such because it lacks public responsibilities)? I think not.

More generally, we can think of the social goods produced by Third sector (non-profit) organizations that deliver care-giving services to people, not only to disabled persons or those with serious pathologies, but also to healthy people who have need of support in terms of educational services, social and health care assistance, sport and cultural services, and so on. It is obvious to point out that the grounds for activity of an associative and network type that we call «the domain of the social,» to use the social term for that which exists between the public and the private (Arendt, 1958), does not only generate good things (relational goods) but also less good things (relational evils). For example, if we ask people who participate in an association whether, in recent years, trust toward other members of the association has grown or decreased, we can have cases in which trust has grown and other cases in which it has decreased. In the case of a relational evil, their answer will be of the following type: «The more I participated in the association, the more I saw that one cannot trust the other members of the association.» Social relations can thus generate negative instead of positive effects. Therefore, it is of the greatest importance to identify the (cultural, structural, agential) conditions in which relational goods, rather than evils, are generated.

Can we make a list of these goods? The type of good about which I am speaking is not a category that can be inventoried, as one does for material goods. This does not mean that we are dealing with a purely ideal good, that is, a value in an abstract or only symbolic sense. It is an intangible good in which energy and resources can be invested and from which energy and resources are drawn. If it is not taken to heart (cared for), the relational good deteriorates and can disappear. In essence, the relational good cannot be catalogued as a functionally specific good but, rather, is a way to gener- 
ate goods - which can be material or not, such as, for example, children's education, the production of consumer goods, a sports team's or an orchestra's performance, a scientific research group's results, the services offered by a volunteer group. These goods would be impoverished, commodified, or bureaucratized if they were not produced in this relational way. Using a questionable expression, we could say that what is important in relational goods is their "mode of production» because relational goods are thus from the generative point of view (regarding how they are generated and work together to generate other goods). This mode of production requires particular social subjects. Precisely for this reason, both the relational goods and the subjects that produce them are fragile and vulnerable. In any case, the type of good that I call relational is not on the same plane as the public-private axis conceived in the modern sense. It exists on another level of reality, a level that is obscured by the public-private axis. How do we manage to see it?

\section{HOW DID THE THEORY OF RELATIONAL GOODS ARISE?}

The theory of relational goods did not arise out of nothingness but germinated in a terrain that had been previously tilled and sowed.This terrain is the one in which, given that social goods cannot be traced back or reduced to the modern categories of public and private, the concept of social private was elaborated.The term «social private» indicates every sphere that is private as regards property and management but which has prosocial ends, and not ends of instrumental expediency for the participants (Donati, 2008: 13-47). Expediency for the participants is not excluded but cannot be the associative end, which must be social solidarity both inside and toward the outside. The conceptual category of the social private is incomprehensible for modern political and economic thought for which private actors are necessarily self-interested; otherwise, they must be impersonal (public) actors (aut... aut). For the modern economy, a private subject can only be one who pursues interests that are primarily to his/her own advantage. Non-profit or private charitable entities, which do not act for private interests, are indeed contemplated as positive initiatives, particularly in order to remedy social ills, but are not considered to be subjects that produce socially and economically significant goods.

At the time that the concept of the social private was first proposed (Donati, 1978: 112-114), there was still no relational theory of the social sphere available that should have underpinned a redefinition of the social private as a possible space for the emergence of relational goods. The notion of the 
social private, in any case, involved a conceptual framework that was completely new with respect to the sociological approaches then in existence; in particular, it aimed to overcome the dualisms peculiar to modernity. In 1988 this author defined the relational good in the following terms:

Saying that human life is a "relational good» means to say that it is a type of shared good that depends on the relations enacted by subjects toward one another and that can be enjoyed only if they orient themselves accordingly. Human life is the object of enjoyment (and thus of rights) not as an «individual» (in the sense of individualistic) good nor a "public» (in the modern technical sense) good, but precisely as a common good of the subjects that are in relation. Such a good must be defined not as a function of individual experiences taken singularly (privately) or collectively, but as a function of their relations. (Donati, 1989: 161-182).

In 1989 an American scholar, Carole Jean Uhlaner, used the term relational goods to indicate local public goods produced by the sharing of the political objectives of people who encounter one another repeatedly (Uhlaner, 1989: 253-285). For her, relational goods are goods that cannot be enjoyed alone. Examples would include participation in a choir, soccer team, or some group volunteer activity. There is some relation between this idea and the model of joint production or the concept of «crowding in.» The definition of relational good that Uhlaner gives is the following:

Assuming that people are restricted to such ends [optimization of individually possessed goods] is neither necessary nor useful. People also pursue relational goods which cannot be acquired by an isolated individual. Instead, these goods arise as a function of a relationship with others. The relational goods can only be possessed by mutual agreement that they exist after appropriate joint actions have been taken by a person and non-arbitrary others $^{4}$ (Uhlaner, 1989: 254).

These are thus goods (also things) produced by the consensus achieved among a certain number of subjects having interpersonal relations: an example could be deciding together to vote for a certain candidate in political elections.

The concept of relational good helped Uhlaner explain political participation in democratic states. Uhlaner wanted to understand why and in what way individuals actively participate in political life notwithstanding the sentiment that the individual vote has little influence on an election's outcome. She found the answer in a model centered on individual rationality. In her view, relational goods are the product of rational individuals who together

4 In an attempt at identifying their nature, she adds: "Relational goods can only be shared with some others. They are thus unlike private goods, which are enjoyed alone, and standard public goods, which can be enjoyed by any number. Relational goods are a subset of local public goods, as they enter into two or more persons' utility function» (Uhlaner, 1989: 254). 
mobilize themselves in view of political elections in the same way as groups are organized to make political demands in everyday life. Relying on the rational choice approach, Uhlaner treated relational goods as public goods, an understanding of them that is completely within modernity and completely American. Since this author uses a rational choice approach (even if it is revised on the basis of a broader spectrum of strictly utilitarian motivations), her concept of relational good has had broad repercussions and has been widely used by economists.

Those who have followed in Uhlaner's footsteps, such as, for example, the economists Antoci, Sabatini and Sodini (2012: 802-814) have treated relational goods as «things» chosen by individuals in cooperative games. Social relations are considered as means for obtaining material goods: hence, these authors' thesis according to which relational goods are interchangeable with material things for the purpose of obtaining people's well-being. These are clear distortions of the concept of relational good because the relational good is not fungible (it is not interchangeable) with material goods. It does not consist in the well-being that it procures to individuals but, rather, in the relation among them, upon which this well-being depends.

In the past two decades economists have used the concept of relational good in various ways, but they have done so without having a suitable theory of social relations. For mainstream economists, in fact, social relations are individuals' intentional projections and strategic choices. Relational goods are considered to be social relations that take on a particular affective quality and foster cooperative rather than competitive games.

For example, Benedetto Gui defines relational good as a special «encounter» between persons who exchange goods with a particular reciprocal fellow-feeling for each other; for him, relational goods are interpersonal relations that have a value to invest in for expressive reasons that make transactions more sympathetic and friendly (Gui, 1996: 260-278). Following Gui, Robert Sugden defines relational goods as the affective and sentimental components (the latter understood as fellow-feeling) that support norms of cooperation (Gui and Sugden, 2005). These goods are the added value created by doing something together as opposed to doing it alone. This added value consists in the people's affective states that assist individual cooperative action. Here we are straddling economy and psychology within methodological individualism. For these authors, relational goods are found in markets for care giving services but also where the interaction is minimal, as in a walk in the mountains with a fellow hiker, for example. They are a source of direct value because they procure pleasure and individual well-being but are also of indirect value since they support the 
motivations necessary for generating the trust and reciprocity that serve economic growth. The tradition in which the thinking of these authors is operating is that of A. Smith, and their analysis remains firmly anchored to economic debate.

In synthesis, for Uhlaner, Gui, and Sudgen, as for mainstream economists in general, relational goods do not coincide with relation as such because the relation is assessed from the point of view of feelings and individual action. For these authors, for example, friendship is a relational good in that, since it is constituted by interactions repeated with a certain affectivity, it grants a certain empathy and amiability to relations among people. The relational good is a quality of interactions that are repeated, leading to the sharing of something. In this way, the fact that the relational good is a relation that has its own reality (the relation's order of reality) is totally misunderstood. The fact that such a relation emerges because of reciprocity among participants is obscured.This is the reciprocity of the We-relation, which confers the quality and powers peculiar to the relational good. Moreover, in relational goods the "why,» that is, the motivation that propels one to act toward the other, is an essential element that cannot be reduced to convenience, even to an affective and sentimental sense of ease and, more generally, to the sense of well-being that individuals derive from the relation. ${ }^{5}$

A conception of relational good built on these bases cannot grasp the fully relational sense of the goods of which we are speaking.

\section{THE TURNING POINT}

A turning point in the definition of relational good came about when it was proposed to classify social goods on the basis of two axes, depending on whether the consumer is sovereign/non-sovereign and consumption is competitive/non-competitive (see figure 1). In this way, private goods are conceived as those characterized by a sovereign consumer and competitive consumption (cell 4), public goods are those characterized by a non-sovereign consumer and non-competitive consumption (cell 1) while in the second cell (non-sovereign consumer and competitive consumption) we find another type of goods, that is, secondary (i.e., associative) relational goods. In

5 As Aristotle already reminded us, the highest friendship, which contributes to eudaimonia/happiness, can never be instrumental because it is a virtue. 
the third cell, we find goods with a sovereign consumer and non-competitive consumption.

\begin{tabular}{|l|c|c|}
\hline & $\begin{array}{c}\text { Non-competitive } \\
\text { consumption }\end{array}$ & Competitive consumption \\
\hline $\begin{array}{l}\text { Non-sovereign } \\
\text { consumer }\end{array}$ & $\begin{array}{c}1 \\
\text { Strictly public good }\end{array}$ & \begin{tabular}{c} 
Collective relational good \\
\hline $\begin{array}{l}\text { Sovereign } \\
\text { consumer }\end{array}$
\end{tabular} \\
\hline
\end{tabular}

Source: P. Donati, La cittadinanza societaria [Societal Citizenship], Laterza, Roma-Bari 1993 (2002), ch. 2.

\section{Figure 1}

The four fundamental types of goods produced in society

Arrow A in figure 1 (between cells 1 and 4) indicates that private goods (lib) and public goods (lab) can be converted one into the other (the line is broken because this is a possibility). For example, if a set of private subjects that produce goods (such as electrical energy, transport, health services, etc.) are nationalized, private goods become public.Vice versa, if a good produced in a monopolistic system (such as telephone service, rail transport, the management of a water network, etc.) is entrusted to the competition of private subjects, we have the privatization of public goods. The user still receives the same functional service (even if at different prices). The nature of the good or service produced does not change.

Unlike private and public goods, relational goods are not interchangeable. They can indeed become private or public goods, but with this they perish because they lose the qualities and powers that are peculiar to them: they lose their peculiar relationality - which does not happen when there is the privatization of public goods or when private goods become public (these goods can certainly change in certain ways but do not alter their functionality with respect to the service that they provide).

Arrow B in figure 1 (between cells 2 and 3) indicates that interchanges between primary relational goods and collective relational goods always exist 
(for this reason, the line is solid). Empirical research demonstrates that there is continuity, and not discontinuity, between the relational goods produced in primary groups and the relational goods of larger and more formal organizations (Donati and Prandini, 2007: 209-223;Tronca, 2008). Primary relational goods contribute to reinforcing secondary relational goods, and vice versa.

This scheme has had various subsequent empirical confirmations of its validity, in particular, the connections between a community's or association's social capital and the production in it of relational goods (Pendenza, 2008).At this point, I would like to synthesize what we know today about the requirements, qualities, and properties of relational goods.

A) Requirements. In order to come into existence, the relational good requires:

i) a personal and social identity of the participants; no relational good exists between anonymous subjects because the relational good implies that the actions that the subjects bring into existence refer to each one's identity as a personal and social being;

ii) a non-instrumental motivation of each subject in his/her involvement with the other: interest toward the other must be characterized by caring; it must be about taking care of the other and not turning to the other to use him/her for some purpose other than the good that is intrinsic to the reciprocal relation as a good in itself, notwithstanding that it could also yield other outcomes (that is, positive externalities and an added social value);

iii) that conduct is inspired by the rule of reciprocity: where reciprocity signifies symbolic exchange and not a do ut des; reciprocity implies that ego gives to alter that which alter needs or could give him/her pleasure, knowing that alter will do the same for ego when ego will have need of it;

iv) total sharing: the relational good can only be produced and used together by those who participate in it, that is, it comes into existence if and only if the participants generate and enjoy it together; no one can produce it alone or can ask others to produce it without him/her, even only temporarily.

v) in general, it requires elaboration over time (the relation's temporal history) and a simple interaction in the moment is not sufficient, such as, for example, an act of kindness or reciprocal empathy in a purchase 
or in an exchange of objects; in short, the temporal register must be historical-relational and not interactional; ${ }^{6}$

vi) a reflexivity that operates relationally, thus, not a reflexivity of an autonomistic type or one that is blocked or fractured; relational reflexivity is required in order for identity, reciprocity, and sharing to be enacted with reference to the good of the relation (as such), which must be produced and enjoyed together by the participants.

B) Qualities and properties. The relational good has the following qualities and properties:

i) it is an emergent effect, cannot be acquired otherwise, and is a way of satisfying primary needs. Saying that it is an emergent effect means that it requires a certain combination (not a simple aggregation) of factors, elements, or components as discussed above; its emergent character accents the fact that the relational good is a «third» entity that exceeds the involved subjects' contributions and that, in certain cases, may not have been foreseen or thought of as the initial intention;

ii) it can be produced and benefited from only by means of the relations that make that good, and it cannot be exchanged or replaced by anything else; in particular, it cannot be bought with money and cannot be produced on command or by law;

iii) it is a good in that it corresponds to the fundamental primary needs of the buman person and social groups, needs that have to do with sociability without which individuals would be monads unable to realize themselves and be happy.

On the other hand, relational evils are the product of relations that do not have these ingredients and qualities. In relational evils we observe the lack of or deficit in one or more of the necessary elements (identity, non-instrumental motivations, reciprocity, sharing, temporal duration, reflexivity) or a lack of coherence or harmony among them. Above all, the relational evil is today connected to those pathological forms of reflexivity that are designated as blocked, hindered, or fractured reflexivity (Archer, 2003).

In essence, relational goods are those immaterial entities (intangible goods) that consist of social relations that emerge from subject reflexively

6 For the three registers of social time (interactional, relational, and symbolic): cf. Donati (2011: 179181). 
oriented toward producing and enjoying together, in a shared manner, a good that they could not obtain otherwise.

We could ask what the role of relational goods is in relations, even dialectical relations, between the state and civil society. To say it synthetically, relational goods are the new common goods, no longer understood as public things or public properties, but as goods co-produced by networks of persons and social formations (the relational subjects) that generate them and benefit from them continuously without their having an «owner». In the following sections we shall explore this theme more deeply.

\section{THE CONCEPT OF RELATIONAL GOOD REDEFINES THE MAP OF COMMON GOODS}

The common good is often identified with the public good. Relational theory, instead, posits a distinction between these types of goods. The common good should not be confused either with the private good or with the public good. What characterizes the common good is the fact that the advantage each person derives from belonging to a certain association or community cannot be severed from the advantage that others also derive from it. This means that each person's interest is realized together with that of others, not in opposition to it (as happens with the private good) nor apart from others' interest (as happens with the public good).

In this sense, the term "common» (communis) is opposed to "proper» (proprium in the sense of "one's own») as "public» is opposed to "private». That which is not one's own (private) nor of everyone indiscriminately (public) is common. The common good is the space of that which not only belongs to some people or even to everyone indifferently. It is not a collective good in the modern sense of a «state» good (belonging to the state). It is the privileged space of social relations when subjects are oriented toward promoting the good of the relations existing among them and thus, also, toward caring for the objects that represent these goods (that is, common goods): for example, a shared house or a commons on the internet (such as Wikipedia).

The common good, in its relational version, is not a concertative idea either, as some understand it to be. It is not the practice of political concertation typical of the neo-corporate democratic government. In the latter arrangement, actors hold biased interests and lay claim to them by taking a seat at a table from which they hope to rise seeing them satisfied, at least in good part, after a conflict characterized by bargaining. The relational good is not of this type. It puts the good of relations before that of individual, group, 
or categorical interests. The relations alluded to by this good are those of subjects involved in the common needs that also pertain to the surrounding societal community.

The criterion for identifying those particular common goods that are relational is based on the principle of positive reciprocity ${ }^{7}$, and not on that of equality of individual opportunities (at the start or as a result), which is peculiar to individualism. Let us think about what this means for the relationships between the genders. Today, the common good between men and women is generally understood as the sum of individual goods acquired through individual opportunities. This happens in the couple, for example, as well as in the job market where men and women face one another.The so-called "pure relation» theorized by A. Giddens (1992) is a relation in which each partner negotiates the maximum individual satisfaction; it is not a relational good. The equal opportunity programs in the work place try to equalize access to jobs and compensation between men and women as individuals; they do not have as objective the pursuit of a relational good. Instead, the relational good is a relation of reciprocity (or «symbolic exchange») between individuals which aims to build relational goods for and between them such as, for example, the balance between work and family life. Relational goods come from being in a relation of full reciprocity.They are neither an aggregation of individual goods nor a collective good that must be distributed among the participants. Relational goods are sensitive to intersubjective relations and cannot be the result of individual advantages (they do not guarantee that each person can pursue his/her own particular interest if this is incompatible with the common good).

Relational goods are the subset of common goods that can only be generated together: no one who takes part in them can be excluded from them; they cannot be sub-divided and are not the sum of individual goods. Saying that a common good is relational means that it is a type of good that depends on the relations enacted by the subjects toward one another and can be enjoyed only if the subjects orient themselves accordingly. In this sense, we say that human life is a common good in that it is the object of enjoyment and therefore of rights, not as a private, individual good in an individualistic sense, nor as a public good in the modern technical sense of a

7 The term reciprocity here indicates relations in which the subjects give to one another and exchange things or services or, in any case, help one another in turn in a social network that acknowledges itself to be a circle of subjects cooperating among themselves. While being useful, reciprocity is not activated and maintained for instrumental reasons but for reasons of identity in belonging to a community of reciprocal assistance. For this reason, sometimes the term «reciprocity» is interchangeable with that of «symbolic exchange». See Godbout (2007). 
state good, but precisely as a relational good of subjects who are in relation with one another.

Present day society expresses the need for new common goods in a very precise phenomenological sense: common goods in the sense that only communities of people, only primary and associative groups, can express and safeguard them.This is a new generation of rights; precisely, the generation of buman rights, beyond civil and political rights and those of socio-economic welfare. When we appeal today, for example, to the child's right to have a family that cares for him/her, we are appealing to a right that is human, not civil in the modern sense of the term ${ }^{8}$ or political or socio-economic. What category of rights is this? The answer cannot but be: a human right that is intrinsically relational.

The legal system has only recently begun to understand the need to introduce this category of rights. We are referring to the type of rights that we can call relational because they involve a relational good (not a public or collective good). Beyond the grand assertions contained in international and national documents on civil rights of a liberal-individualistic matrix, it is necessary to develop a specific reflection on people's rights to common goods and on the rights of common goods as such, in as much as they are relational goods. The latter are rights pertaining to those relational goods that enjoy the status of legal subjectivity (for example, a social cooperative: these are the rights of the cooperative and not only the rights of the individuals in the cooperative). This is a new area for reflection and social practices that is beginning to come to the fore in a mature way only today.

The proof that today's public ethics does not involve a common good in a relational sense is found in the case in which, for example, the problems of peace, development, the environment, and also of new forms of poverty, are not confronted as problems of concrete human relations enacted by co-present subjects but are simply treated as «things» to eliminate by marginalizing violent persons, punishing those who do not succeed in competing, banning polluters, helping the poor with measures that promote passivity. Problems are confronted by putting people in conditions of not causing trouble. These are false solutions to problems because they are not inspired by the common good in that they leave aside completely the necessity of involving poor and marginalized people, deviants, and even those prone to violence in seeking to solve problems as common, shared problems. In the arena of social policies, it is very clear by now that these modalities for facing situations of distress,

8 I remind the reader that the term «civil rights» refers to the individual rights promoted by market liberalism starting in the 1700's (as the right to religion, opinion, association of the individual, and also the right of the person to physical integrity, due process in court proceedings, etc.). 
poverty, and social marginalization are completely unsatisfactory. Peace, development, a clean and safe environment, a decent life for everyone - these are all goods that correspond to the relational character of these objectives: this is to say that they can only be achieved together; they are not a sum of individual expediencies but a function of the relational system that connects subjects in relation with one another and a function of their comprehensive internal and external relations.

\begin{tabular}{|c|c|c|}
\hline & Non-competitive goods & Competitive goods \\
\hline $\begin{array}{l}\text { Agent/ } \\
\text { Actor is } \\
\text { con- } \\
\text { strained }\end{array}$ & $\begin{array}{l}\text { In strictly public goods, } \\
\text { relations are binding apart } \\
\text { from individual interests } \\
\text { (constrictive sharing) } \\
\text { [whoever does not adapt is } \\
\text { considered to be a deviant or } \\
\text { a free rider] }\end{array}$ & $\begin{array}{l}\text { In secondary relational goods, } \\
\text { relations are bound to prosocial } \\
\text { ends, which means that individual } \\
\text { interest depends on the relations } \\
\text { that make up the common good, } \\
\text { which has positive externalities } \\
\text { for unknown others [whoever } \\
\text { does not adapt weakens the } \\
\text { common good or generates } \\
\text { relational evils] }\end{array}$ \\
\hline $\begin{array}{l}\text { Agent/ } \\
\text { Actor is } \\
\text { free }\end{array}$ & $\begin{array}{l}3 \\
\text { In primary relational goods, } \\
\text { relations are characterized } \\
\text { by the symbolic exchange } \\
\text { among those who belong to } \\
\text { a primary group (face-to-face } \\
\text { group) [whoever does not } \\
\text { adapt weakens the group or } \\
\text { generates relational evils] }\end{array}$ & $\begin{array}{l}4 \\
\text { In strictly private goods, relations } \\
\text { are purely instrumental or } \\
\text { irrelevant [whoever does not } \\
\text { adapt decreases his/her ability to } \\
\text { compete] }\end{array}$ \\
\hline
\end{tabular}

Figure 2

Four areas of social relations differentiated on the basis of degrees of actors' freedom and the type of good produced (public goods, primary and secondary relational goods, private goods in a strict sense)

Relational goods are the key for moving from the welfare state to the welfare society. It is important to underscore that the common good takes on the form of a relational good in all the areas of welfare in which relations among human subjects are in play. Figure 2 synthesizes the various areas in 
which socially significant goods are produced. Relational goods are found in the areas defined by cells 2 and 3. Outside of these areas of welfare, we find non-relational goods (and subjects). On the one hand (cell 1), we find public goods in a strict sense, which can and must be pursued through systemic or technological, redistributive apparatuses (such as the state's fiscal revenues, public pensions, the state's monetary transfers, services in which people's participation is bound and constrained on the basis of legal requirements). On the other hand (cell 4), we find those strictly private goods (of the Darwinian market) that, in order to be satisfied, do not necessarily require a relation involving cooperation and reciprocity between buyer and seller.

It is nonetheless necessary to clarify that collective relational goods (secondary, associational), while they are peculiar to the Social private and Third sectors, can also be generated in the state and Market on condition that actors comply with the requirements that are specific to relational goods (which were discussed in section 4) because where they are produced is not important but rather bow they are produced. They can be pursued within each of these spheres and between them. The fact that in the lib-lab arrangement they are weakened and marginalized depends on the non-relational way in which the lib-lab system has until now configured the state and market and their relationships.

\section{WHO ARE THE SUBJECTS WHO GENERATE RELATIONAL GOODS? AND UNDER WHICH CONDITIONS?}

Generally speaking, relational goods are the product of processes of association among individual agents/actors. The agents/actors can also be collective. But in that case the conditions for generating relational goods are much more complex and onerous. For this reason, it is quite rare that relational goods are able to emerge among collective subjects. It is necessary that the social context be non-competitive (that is, not combative). Relational goods can be and, indeed, are competitive goods, but in terms of solidarity in the sense of competition (cum-petere) as the search for the best solutions in a contest which is not detrimental to the other participants but stimulates each participant to contribute his/her best effort toward achieving the same common goal.

For example, the components of the same sports team can create the relational good of their team. But a game played between two football teams, as in every competitive activity that must lead to a victor or, at least, to a ranking of winners and losers, cannot create a relational good. The combative con- 
text and its rules prohibit this. Instead, a second level organization that unites two or more mutual aid associations for the purposes of reciprocal cooperation can, under certain conditions, create relational goods and therefore can be a relational subject that creates relational goods among participating associations.

Relational goods are produced by those relational subjects that operate according to the characteristics highlighted in the preceding sections ( 4 and 5). Figure 3 synthesizes the placement of relational subjects in the societal arena.

We can find them in life-world spheres as primary groups and in the spheres of civil society as Third sector organizations and volunteer associations. Collective relational subjects do not necessarily have to be bound to any particular territory because means of communication can also create associative forms at a distance. However, the distance must allow for a minimum of intersubjective relations. Figure 3 tells us that relational subjects cannot arise and exist either in the bureaucratic organizations of states (state apparatuses, such as the public administration) (cell 1) or in the capitalistic market of a Darwinian type (cell 4).

\begin{tabular}{ccc} 
& $\begin{array}{c}\text { The goods produced are } \\
\text { non-competitive }\end{array}$ & $\begin{array}{c}\text { The goods produced } \\
\text { are competitive }\end{array}$ \\
$\begin{array}{c}\text { Agents/ } \\
\text { actors } \\
\text { are con- } \\
\text { strained }\end{array}$ & $\begin{array}{c}\text { State Apparatuses } \\
\text { (Public Administration) }\end{array}$ & $\begin{array}{c}\text { Collective relational subjects con- } \\
\text { stituted by organizations of the } \\
\text { social private sphere, third sector, } \\
\text { civil associations, and NGOS } \\
\text { (I) }\end{array}$ \\
$\begin{array}{c}\text { Agents/ } \\
\text { actors are } \\
\text { free }\end{array}$ & $\begin{array}{c}\text { Primary relational subjects } \\
\text { constituted by primary groups } \\
\text { (families, informal networks) } \\
\text { (L) }\end{array}$ & $\begin{array}{c}4 \\
\text { Capitalistic market }\end{array}$ \\
\hline
\end{tabular}

Figure 3

The placement of relational subjects among the four fundamental types of social subjects (distinguished on the basis of degrees of agents/actors' freedom and the type of goods produced) 
Primary relational subjects are those characterized by intersubjective, face-to-face relations (in cell 3 of figure 3). Secondary relational subjects (in cell 2) are created in the social networks that weave together formal (professional) relationships and informal (non-professional) relationships on condition that the organizational relations are not purely functional but leave space to superfunctional action. ${ }^{9}$ The specificity of these networks resides in the fact of being institutions of social solidarity that produce positive externalities for third subjects and operate as training grounds for substantial, that is, civil democracy.

Relational subjects can be distinguished at three levels: micro, meso, and macro.

i) On a micro level we find families, small groups, and informal networks that practice internal intersubjective relations with a relational reflexivity. Emblematic examples are many self- and mutual-help groups that present the characteristics discussed in sections 4 and 5 .

ii) On a meso level we find organizations that are broader and have a certain formalization of their structures and activities. These are the organizations of the social private sphere, the Third sector, and civic associations such as associations of social promotion, volunteer organizations, social solidarity cooperatives, and social networks on the internet. These can also be for-profit economic enterprises on condition that they practice corporate social responsibility, that is, that they have as an objective the production of positive externalities (relational goods) in favor of the surrounding community and that this objective is not instrumental to making a profit for the company but is envisioned as an ethical criterion of entrepreneurial activity. This is the civil economy.

iii) On a macro level we find second and third level organisms that organize lower level relational subjects in an associative manner. We can think of those international non-governmental Organizations that, unlike organizations that lobby States or international institutions, create a network of local associative units that operate on a micro scale. Once again, it is necessary here to see whether there exist or not the conditions peculiar to a relational subject's action.

9 With the term «superfunctional,» we mean an individual or organizational action that is not oriented toward the specialization of roles (that is, it is not guided by functional differentiation) but is oriented toward the exercise of a plurality of functions that cannot be enumerated - and can also be latent - in that it operates with relations, on relations, through relations. In order to understand the superfunctional reality of the social sphere, it is necessary to abandon modernity's functionalistic approach as was theorized by Talcott Parsons and Niklas Luhmann. 
We might wonder whether certain international organisms can be or become relational subjects. These could be the un, the European Union, or the Mercosur. The probability that organisms of this type can be relational subjects is practically zero owing to the fact that they never have the conditions of intersubjectivity and reflexivity that are necessary for producing relational goods. These are, generally speaking, instrumental organisms that conceive of the common good in aggregative and combinatorial terms, and never in relational terms. Nevertheless, in the abstract, we could imagine that in the future it would be possible to create macro level organisms that adopt a relational culture and realize at least some of the conditions peculiar to relational subjects.

\section{THE NEW CIVIL DEMOCRACY}

Civil democracy (as distinct from economic, political, and social democracy) is the form of societal governance that pursues the common good not as a state of things, nor as a sum or aggregation of single goods, nor as a super-ordinated reality, but as the totality of those conditions of social life that allow groups, as well as their individual members, to achieve their own perfection more fully and quickly through the creation of relational goods.

Over the course of the 20th century this vision was translated into the idea that ensuring the conditions for the development of people and their social formations meant providing assistance and state sponsored redistribution using resources coming from the market. This way of thinking and acting came from afar. It was a legacy of the Enlightenment State inspired by concern for the population's well-being and managed from above as a form of "good government» (politeia). It materialized starting from the absolute and later constitutional States established in Europe between the 17th and 19th centuries.

Today we find ourselves facing a distinct historical discontinuity. With respect to the past, generating the common good presupposes the relational participation of all those interested in such a good (which cannot be abstract entities but concrete personal and associative subjects in specific situations) and presupposes the nexus between each actor's freedom and responsibility in producing the common good. Those who make reference to the classical political conception continue to identify the common good in the state, as its function and chief task. But there is a clear shift, even if it is gradual and tempered, of the concept of common good toward non-state political communities. The new welfare cannot be produced either only from below (from 
individuals), nor only from above (by an increasingly interventionist State), nor from a generic mixture of the two paths, but rather from a suitable relation - involving both subsidiarity and solidarity - among the members of a political community (understood precisely as the totality of those who must decide on their common good).

To arrive at a concrete definition of this vision, social theory must clarify the reality of the relational order, that is, the reality of the relations that substantiate the common good, and must see its autonomous potentialities in what we could call the «subjectivity of society,» which means seeing it in the capacity of civil society (defined as the totality of subjects - both individual and collective - that do not have roles in public institutions) to express social subjects (we should say «societarian» subjects) that generate relational goods.

To this end, it becomes essential that there is integration between visions of the common good which imply different perspectives of what is called the principle of subsidiarity: the common good which only a political authority can guarantee from above (vertical subsidiarity, internal to the state hierarchical system), the common good which is peculiar to the relations between the state and civil subjects (which may be a borizontal subsidiarity, when a state apparatus promotes an action for the benefit of one or more civil subjects independently, or a circular subsidiarity, when state and civil subjects act as reciprocal partners on a symmetrical ground), and the common good as defined in the relations among civil subjects only (lateral subsidiarity, for instance between companies and families).

\section{IMPLICATIONS FOR THE FUTURE POLITICAL ORGANIZATION OF SOCIETY}

To the degree that the limitations and structural defects of the current model of the social (welfare) state can be seen, the alternative idea of a society based upon a sound combination of subsidiarity and solidarity gains ground, a society that is pursued through the expansion of relational goods. This goes beyond a neo-lib/lab vision of the social State and of well-being because it emphasizes three fundamental things.

First, it redefines well-being starting from subjects, which are simultaneously its recipients and architects. Second, it confers on the state the political role of guarantor of the common good, in as much as it decides the general rules but does not produce civil society or, even worse, a power system that sees (reads, interprets, enacts) civil society as a function of political hege- 
mony.Third, it abandons the philosophy which aims at including people in a single institutional order to embrace, instead, that of promoting different institutions in a plural order which rewards the best results obtained through the adoption of the principles of subsidiarity and solidarity.

It is indeed evident that civil society produces relational goods if and to the extent that it makes use of its own resources: in the first place, its moral resources (i.e., values and virtuous behaviors), which involve relying on a first person, rather than a third person, ethics. The failures of the lib-lab configuration of society are due to the fact of having extolled third person ethics, abandoning, indeed destroying, first person ethics.

We could ask: why is the societal vision of the common good as a relational good, inflected in terms of a subsidiarity characterized by solidarity, more human? This is due to three reasons, basically. First, because it not only respects the choices of negative freedom (freedom from constrictions) but nourishes the choices of positive freedom (freedom for - i.e. in favor of social finalities) of people and social subjects. Second, it does not forcibly impose solidarity but produces it by incentivizing and rewarding whoever adopts courses of action that produce relational goods. Third, it does not privilege exit solutions or those of mercantile competition but, rather, those that strive toward the construction of social autonomies able to combine universalism and particularity.

The superseding of the 20th century social State in the direction of a political system that promotes a civil society that can face the challenges posed by a globalizing world that generates ever new crises is not a simple operation. Certainly, it cannot be achieved within the framework of negotiations and compromises between market and political democracy, merely conceding gracious acknowledgements to the Third sector, which remains residual and dependent on the first two sectors. The passage to a new social order is happening today under the aegis of a social morphogenesis (Archer, 2013) that is enfranchising an «other» civil society with forms of sociality that are different from those of political institutions and the capitalistic market (Bruni and Zamagni, 2009).

Modernity asked itself whether the social State should have been all of or only a part of society. It has oscillated, in its ideologies and practices, from one pole to the other, configuring the state as the synthesis of everything (polarization of a $l a b$ type) or, vice versa, as a residual sub-system (polarization of a lib type). We risk remaining stuck in this game. To the question that modernity bequeaths to us, and that is, «Must the state still be everything or only a part?», the 21 st century could answer by completely shifting perspective and configuring the state as a differentiated function of the political 
body specialized in making sure that social processes do not create poverty and exclusion but, rather, wealth and social cohesion through the production of relational goods. It addresses everyone (not only the poor), but as to this «everyone,» it is interested in what has to do with their conditions of participation seen as the result of a triangulation among risks undertaken, responsibilities assumed, and opportunities enjoyed. This means seeing the state as the specific sub-system that must politically govern society but must not replace it, nor colonize it, nor produce it. The State must come to a stop in front of that which does not pertain to it, that which is not available to it, such as the ethical sphere. It must be a means through which the community takes on the collective responsibility to include in social life those who cannot or do not succeed in becoming part of it.

The society of subsidiary solidarity has its political form in what we could call the «relational social State.» What is a relational State? In our opinion, it is characterized by the following modalities of configuration. ${ }^{10}$

1) The relational State is no longer conceived as the Vertex and Center of society but as a functionally differentiated political-administrative sub-system for the governance of a society that is observed and enacted as a network of social (public, private, and mixed) subjects and institutions. In its aspect of institution, the state becomes an ensemble of apparatuses that have specific political and administrative functions that must operate in a manner that is subsidiary - and relatively symmetrical in terms of power - with respect to other fundamental sub-systems of society, and that is, the market, civil society, and the sub-system of the family and informal networks.

2) The relational State is configured as a legal and social system that must realize complex citizenship. Citizenship is said to be complex for three orders of reasons:

i) because it recognizes not only civil, political, and economic-social rights (as theorized by T. H. Marshall and others) ${ }^{11}$ but also buman rights, which are the rights of the human person in relation to the social formations in which he/she develops and conducts his/her activities; these refer to over four generations of rights, the last of which is still being defined;

10 For more details see Donati (2004: 9-47).

11 Cf. Marshall (1992). 
ii) because it interweaves citizenship in a state (traditional citizenship, defined as the individual's belonging to a national State) and societal citizenship (defined as persons' belonging to associative forms of civil society that are recognized as collective subjects - which are public but not of the state - acting with politically significant functions in the local, regional, national, or supernational sphere); and, with this, makes possible differentiated and multiple forms of citizenship;

iii) because complex citizenship does not make reference only to individuals but also to social formations of civil society (which constitutes a reason for a sharp discontinuity with modernity); in effect, from a sociological point of view, the relational social State arises when typically modern (from the 19th-20th centuries) political constitutions are reformed through processes of constitutionalizing private spberes, that is, by attributing a political value (authorizing binding collective decisions for the common good), and the connected public functions, to organizations of a non-state type. ${ }^{12}$

The relational State is de/centered and articulated in an associational (or federative) manner, whether upward (for example, the European Union) or downward (local communities and organizations of civil society). The consequences for social policies are of enormous import. The passage from the traditional welfare state to the relational social State entails, in fact, at least three great structural changes.

In the first place, the symbolic code that presides over social inclusion (or cohesion) policies changes: the prevailing symbolic code is no longer that of the state (by which the common good is by definition of the state) but becomes what we can call a relational symbolic code (by which the common good is the relational one). In the second place, social policies become a widespread function of society, that is, a function that is pursued by a plurality of actors, which are public and private, combined and intertwined (in relation) in various ways with one another (plural welfare, societal conceptions, multistakeholders of welfare organizations, and still others). In the third place, the social policies, which until now have been upheld primarily by the two pillars of freedom (the $l i b$ side or that of the market) and equality (the $l a b$ side or that of the redistributive State), must institutionalize a third pillar, that of solidarity, as an autonomous and distinct pole that cannot be derived from the other two. In this pole, ad boc societal, plural, and subsidiary

12 Cf. Teubner (2012). 
welfare institutions arise. Until now, social policies have treated solidarity as a by-product of policies pursued primarily through combinations of individual freedoms and equality of opportunity in welfare systems conceived as a compromise between State and market. It is not by chance that solidarity still does not appear as a value and end in itself alongside the other two values of the European Union's master plan.

The relational social State expresses the need for a jump in quality toward a new configuration of freedom, equality, and solidarity that does not make social solidarity residual in that it does not understand the latter to be charity or compensation for the weakest or marginalized members of society but places it on the same level as freedom and equality of opportunity. It does so also in terms of the elaboration of rights (new relational rights) and the production of goods and services (new relational goods) of welfare.

To synthesize: the relational social State conceives the common good to be a good that valorizes relations of reciprocal enrichment of free and responsible actors who create welfare. It brings about a complex citizenship that operates by valorizing the principle of relationality applied to all of society's spheres. Social policies are not understood as sectorial or residual policies for the poor or needy but as a general form of a reflexive action of society on to itself in terms of the production and distribution of social goods (in a broad sense), without separating normal conditions from particular conditions (those that indicate risk or are deviant or pathological). The relationality that connotes complex citizenship operates at all territorial levels and in every intervention sector as citizenship that must be extended to all potential actors (not as passive beneficiaries but, rather, as active subjects that choose it and put it into practice) (inclusive citizenship) and must be deepened, that is, made to be concrete and situated (deep citizenship). Relational modalities substantially alter the hierarchical, bureaucratic, disciplinary characteristics, as well as those regarding assistance and workfare, that have been typical of the traditional 20th century welfare state.

The contribution of relational subjects to substantial democracy consists in promoting the birth and development of civil welfare institutions that create relational goods by acting with relational reflexivity. Sociological analysis must be able to grasp those phenomena that indicate how morphogenetic society can evolve toward a structural and cultural arrangement able to promote the specific reflexivity that generates common goods as relational goods (Donati, 2012: 1-81). 


\section{REFERENCES}

Antoci, A. et al. (2012): «The Solaria Syndrome: Social Capital in a Growing Hyper-Technological Economy», Journal of Economic Behavior E Organization, vol. 81, pp. 802-814.

ArCher, M. S. (2003): Structure, Agency and the Internal Conversation, Cambridge, Cambridge University Press.

ArCHER, M. S. (ed.) (2013): Social Morpbogenesis, Dordrecht, Springer.

AREndt, H. (1958): The Human Condition, Chicago, University of Chicago Press.

Bottomore, T. and T. H. Marshall (1992): Citizenship and Social Class, London, Pluto.

Bruni, L. and S. Zamagni (eds.) (2009): Dizionario di economia, Roma, Città Nuova.

Cortina,A.et al. (eds.) (2008): Public Reason and Applied Etbics. The Ways of Practical Reason in a Pluralist Society, Aldershot, Ashgate.

Donati, P. (1978): Pubblico e privato: fine di una alternativa?, Bologna, Cappelli.

- (ed.) (1989): La cultura della vita. Dalla società tradizionale a quella post-moderna, Milano, FrancoAngeli.

- (2004): «Nuevas políticas sociales y Estado social relacional», Revista Española de Investigaciones Sociológicas, 108, pp. 9-47.

- (2008): "The Emergent Third Sector in Europe:Actors, Relations and Social Capital» in ANHEIER, H. K. et al. (eds.) (2008): The Social Generative Action of the Third Sector. Comparing International Experiences, Milano, Vita e Pensiero.

- (2011): Relational Sociology. A New Paradigm for the Social Sciences, New York, Outledge.

- (2012): «Beyond the Market/State Binary Code: The common good as a relational good» in SCHLAG, M. and J. A. MERCADo (eds.) (2012): Free Markets and the Culture of Common Good, New York, Springer.

Donati, P. and R. Prandini (2007): «The Family in the Light of a New Relational Theory of Primary, Secondary and Generalized Social Capital», International Review of Sociology, vol. 17, 2, pp. 209-223.

Donati, P. and R. SolCi (2011): I beni relazionali. Che cosa sono e quali effetti producono, Torino, Bollati Boringhieri.

Donati, P. and L. Tronca (2008): Il capitale sociale degli italiani. Le radici familiari, comunitarie e associative del civismo, Milano, FrancoAngeli.

Giddens, A. (1992): The Transformation of Intimacy. Sexuality, Love and Eroticism in Modern Societies, Cambridge, Polity Press. 
Godbout, J. (2007): Ce qui circule entre nous. Donner, recevoir, rendre, Paris, Seuil.

GuI, B. (1996): «On «Relational Goods»: Strategic Implications of Investment in Relationships», International Journal of Social Economics, vol. 23, 10/11, pp. 260-278.

GuI, B. and R. SUGDEN (2005): Economics and Social Interaction:Accounting for Interpersonal Relations, Cambridge, Cambridge University Press.

Marshall, T. H. (1950): Citizenship and Social Class, Cambridge, Cambridge University Press.

Pendenza, M. (2008): Teorie del capitale sociale, Soveria Mannelli, Rubbettino.

PoluInI, G. (2009): «Valori civili, valori familiari ed atteggiamenti civici: il 'familismo civico'?» in GUBERT, R. and G. POLLINI (eds.) (2009): Il senso civico degli italiani. La realtà oltre il pregiudizio, Milano, FrancoAngeli.

Simmel, G. (D. Levine ed.) (1972): Georg Simmel on Individuality and Social Forms: Selected Writings, Chicago, The Chicago University Press.

- (1981): «La sociabilité» in Simmel, G. (1981): Sociologie et épistémologie, Paris, Puf.

TEUBNER, G. (2012): Verfassungsfragmente: Gesellschaftlicher Konstitutionalismus in der Globalisierung, Berlin, Suhrkamp Verlag.

UHLANER, C. J. (1989): ««Relational Goods» and Participation. Incorporating Sociability into a Theory of Rational Action», Public Choice, vol. 62, 1989, pp. 253-285. 